\title{
Kecerdasan Spiritual dan Komitmen Organisasi Mahasiswa Pengurus Organisasi
}

\author{
Tri Yuliani \& Shanty Komalasari \\ Universitas Islam Negeri (UIN) Antasari Banjarmasin
}

\begin{abstract}
Lack of organizational commitment often occurs among students who are administrators of the organization; they are still less able to set rules for themselves. These abilities are related to how one judges and interpret each action or commonly referred to as spiritual intelligence. This study aims to examine the relationship between spiritual intelligence and organizational commitment. The population in this study amounted to 919 people, with a sample of 92 administrators of UKK and UKM in the 2017/2018 period at UIN Antasari Banjarmasin. The sampling technique in this study uses probability sampling with a type of sample random sampling. The instrument of data collection uses the scale of organizational commitment and spiritual intelligence of the Likert model and analysis using Product Moment correlation with the help of SPSS 21.0. Based on the calculation results show that the level of organizational commitment and spiritual intelligence of students is classified as moderate. The results of the correlation test indicate a significant positive relationship between the two variables $(p=0.002, p$ $<0.05)$. The higher the spiritual intelligence, the higher the student's organizational commitment and vice versa, the lower the spiritual intelligence, the lower the student's organizational commitment.
\end{abstract}

Keywords: Spiritual Intelligence; Organizational Commitment; Administrators of the organization; Student

\begin{abstract}
Abstrak
Kurangnya komitmen organisasi sering terjadi dikalangan mahasiswa yang menjadi pengurus organisasi, mereka masih kurang mampu dalam menetapkan aturan bagi diri sendiri. Hal tersebut terkait dengan bagaimana seseorang menilai dan memaknai setiap tindakan atau yang biasa disebut sebagai kecerdasan spiritual. Penelitian ini bertujuan untuk menguji hubungan antara kecerdasan spiritual dengan komitmen organisasi. Populasi dalam penelitian ini berjumlah 919 orang, dengan sampel 92 orang pengurus UKK dan UKM periode 2017/2018 di UIN Antasari Banjarmasin. Teknik pengambilan sampel dalam penelitian ini menggunakan probability sampling dengan jenis sampel random sampling. Instrumen pengumpulan data menggunakan skala komitmen organisasi dan kecerdasan spiritual model likert dan analisis menggunakan korelasi Product Moment dengan bantuan SPSS 21.0. Berdasarkan hasil perhitungan menunjukkan bahawa tingkat komitmen organisasi dan kecerdasan spiritual mahasiswa tergolong sedang. Hasil uji korelasi menunjukkan adanya hubungan positif yang signifikan antara kedua variabel $(\mathrm{p}=0,002, \mathrm{p}<0,05)$. Semakin tinggi kecerdasan spiritual maka semakin tinggi pula komitmen organisasi mahasiswa dan sebaliknya, semakin rendah kecerdasan spiritual maka semakin rendah pula komitmen organisasi mahasiswa.
\end{abstract}

Kata Kunci: Kecerdasan Spiritual; Komitmen Organisasi; Pengurus Organisasi; Mahasisw 
Mahasiswa adalah peserta didik yang terdaftar dan belajar pada perguruan tinggi. Mahasiswa dalam tahap perkembangannya digolongkan sebagai remaja akhir dan dewasa awal, yaitu usia 18-21 tahun dan 22-24 tahun (Fibrianti, 2009). Mahasiswa dengan kesempatan dan kelebihan yang dimilikinya mampu melakukan hal-hal besar dan melakukan perubahan karena mahasiswa memiliki potensi-potensi yang beragam dan bakat-bakat yang bisa menunjang kehidupan baik di akademik maupun di masyarakat. Oleh karena itu, mahasiswa diharapkan mampu menjadi agen perubahan bangsa.

Banyak cara agar mahasiswa bisa melakukan perubahan, salah satunya adalah dengan cara mengikuti organisasi yang ada di kampus. Hampir semua kampus yang ada di Indonesia memiliki organisasi yang beragam dengan tujuannya masing-masing, guna menampung kreatifitas mahasiswa.

Seperti yang ada pada kampus Universitas Islam Negeri (UIN) Antasari Banjarmasin. Kampus ini memberikan pendidikan berbasis agama pada mahasiswa dan memegang konsep berbasis lokal berwawasan global pada setiap gerak yang dilakukan. Selain pendidikan hal lain salah satu hal yang dapat menunjang hal tersebut adalah organisasi kemahasiswaan yang dimiliki. Sesuai dengan data wawancara yang didapatkan, diketahui bahwa terdapat puluhan organisasi mahasiswa yang tersebar di UIN Antasari Banjarmasin, mulai dari organisasi yang bergerak di bidang kemanusiaan, bela diri, seni, musik, olahraga, pecinta alam dan lain sebagainya. Pada tingkat universitas ada 5 UKK (Unit Kegiatan Khusus) dan 14 UKM (Unit Kegiatan Mahasiswa) yang artinya ada 19 bidang organisasi berbeda yang ditawarkan pada mahasiswa. Secara fungsional UKK kegiatan kemahasiswaan ini sama dengan UKM, hanya saja UKK berada dibawah naungan kampus dan juga memiliki jalur organisatoris di luar kampus, seperti UKK Pramuka, Resimen Mahasiswa, Koperasi Mahasiswa, Mahasiswa Pencinta Alam, dan Krops Suka Rela (KSR-PMI). Selain berbagai kelebihan yang ditawarkan tentunya ada juga berbagai kendala yang dialami mahasiswa saat berorganisasi. Menurut hasil observasi dan wawancara beberapa kendala mahasiswa dalam berorganisasi adalah kesulitan mengatur waktu antara perkuliahan dan organisasi. Perbedaan pendapat sesama teman, minimnya fasilitas dandana pada saat kegiatan serta yang sering dialami oleh beberapa organisasi adalah kurang aktifnya anggota ataupun pengurus. Kendala lainnya adalah kurangnya komitmen 
organisasi para pengurus organisasi. Hal ini dapat diketahui dari kurangnya komitmen afektif anggota dalam organisasi. Ikatan emosional yang mereka bangun dalam organisasi masih belum kuat. Selain itu kesibukan dibangku kuliah dan ketidakmampuan membagi waktu menjadi alasan mereka untuk meninggalkan tanggung jawab mereka diorganisasi.

Komitmen organisasi didefinisikan sebagai kekuatan identifikasi dan keterlibatan individu dengan organisasi. Komitmen yang tinggi dicirikan dengan tiga hal, yaitu: kepercayaan dan penerimaan yang kuat terhadap tujuan dan nilainilai organisasi, kemauan yang kuat untuk bekerja demi organisasi dan keinginan yang kuat untuk tetap menjadi anggota organisasi. Komitmen nampak dalam tiga bentuk sikap yang terpisah tapi saling berhubungan erat, pertama identifikasi dengan misi organisasi, kedua keterlibatan secara psikologis dengan tugas-tugas organisasi dan yang terakhir loyalitas serta keterikatan dengan organisasi (Luthans, 2010).

Di sisi lain menurut Allen dan Mayer anggota dengan komitmen afektif yang kuat tetap berada dalam organisasi karena menginginkannya. Anggota dengan komitmen kesinambungan yang kuat tetap dalam organisasi karena membutuhkannya (need to), sedangkan karyawan yang memiliki komitmen yang normatif kuat tetap berada dalam organisasi karena mereka harus melakukan (tought to) (Luthans, 2010).

Allen dan Mayer mengungkapkan bahwa bentuk komitmen organisasi ada 3 yaitu komitmen afektif, kesinambungan, dan normatif. Komitmen afektif merupakan rasa keterkaitan anggota secara emosional kepada pekerjaannya, sedangkan komitmen kesinambungan adalah jenis komitmen anggota yang didasarkan pada pertimbangan tentang apa yang harus dikorbankan jika meninggalkan organisasi. Oleh karena itu anggota memutuskan menetap pada suatu organisasi karena menganggapnya sebagai suatu pemenuhan kebutuhan, dan komitmen normatif yaitu keyakinan anggota tentang tanggung jawab terhadap organisasi dan tetap tinggal pada suatu organisasi karena merasa wajib untuk menjaga komitmen pada organisasi tersebut (Luthans, 2010).

Terdapat beberapa alasan mengapa organisasi harus melakukan berbagai usaha untuk meningkatkan komitmen organisasi, dalam diri para anggota/pengurusnya. Pertama, semakin tinggi tingkat komitmen anggota/pengurus, maka akan semakin tinggi pula usaha mereka 
untuk mengerjakan pekerjaannya. Kedua, semakin tinggi tingkat komitmen anggota/pengurus terhadap organisasi/instansi, maka semakin tinggi pula produktivitas kerjanya. Ketiga, dengan adanya komitmen, maka pengunduran diri anggota/pengurus akan berkurang, jadi organisasi tidak perlu membuang waktu dan biaya yang tinggi untuk melakukan pergantian anggota/pengurus. Keempat, dengan adanya komitmen, maka tidak diperlukan lagi adanya pengawasan dan proses pemantauan yang kaku, menyita banyak waktu dan berbiaya mahal (Luthans, 2006).

Sebagai seorang mahasiswa yang sudah memasuki masa dewasa seharusnya mahasiswa mampu menjalankan kewajiban dengan baik, dan mengatur setiap tindakan yang akan dilakukan. Kemampuan untuk mengatur diri sendiri atau bertanggungjawab terhadap diri sendiri, terkait dengan bagaimana seseorang menilai dan memaknai setiap tindakannya. Kemampuan untuk menilai makna tindakan dan makna hidup ini berkaitan erat dengan kecerdasan spiritual yang dikemukakan oleh Zohar dan Marshall (2007). Mereka menyebutkan bahwa kecerdasan spiritual sebagai kecerdasan individu untuk menilai makna dari tindakan yang dilakukannya.

Pada mulanya kecerdasan seseorang hanya dilihat dari kecerdasan kognitifnya saja, namun pada perkembangannya, kecerdasan IQ bukanlah satu-satunya indikator kecerdasan, yang dapat membawa kesuksesan seseorang. Paradigma baru mengenai kecerdasan adalah kecerdasan spiritual. Zohar menyatakan bahwa kecerdasan spiritual merupakan tiang penyokong IQ dan EQ. Dimana IQ dan EQ merupakan kecerdasan yang dapat dilihat (tangible), sedangkan SQ (kecerdasan spiritual) tidak demikian. Pemahaman tentang kecerdasan dan aplikasinya tergantung pada personal values masing-masing orang. Menurut Ary Ginanjar (2016) kecerdasan spiritual adalah kemampuan untuk memberi makna ibadah terhadap setiap perilaku dan kegiatan, melalui langkah-langkah dan pemikiran yang bersifat fitrah, menuju manusia yang seutuhnya (hanif), dan memiliki pola pemikiran tauhidi (integralistik), serta berprinsip "hanya karena Allah"

Kecerdasan spiritual menurut Ginanjar (2016) bisa terus diasah dan ditingkatkan melalui berbagai cara, artinya kecerdasan spiritual tidak seperti IQ (Intelektual Quotient) yang 
cenderung memiliki angka tetap atau sukar berubah. Belajar ilmu-ilmu agama diperguruan tinggi bisa menjadi salah satu cara yang bisa dipilih untuk mengasah kecerdasan spiritual.

Kecerdasan intelektual atau emosional menurut Sunar (2010) tidak cukup untuk membuat seseorang memiliki komitmen yang tinggi pada organisasi, diperlukan kecerdasan lain seperti kecerdasan spiritual. Kecerdasan spiritual sangatlah penting untuk lebih menyadarkan mahasiswa tentang tugas-tugas yang mereka miliki saat mereka berorganisasi maupunkuliah. Karena orang-orang yang memiliki kecerdasan spiritual yang tinggi mampu memaknai penderitaan hidup dengan memberi makna positif pada setiap peristiwa, masalah, bahkan penderitaan yang dialaminya. Dengan demikian, mahasiswa yang memiliki kecerdasan spiritual yang tinggi diharapkan dapat membentuk mereka menjadi pribadi yang cerdas, ikhlas, memilikimisi hidup yang jelas, memiliki kesadaran yang tinggi dan memiliki kepekaan sosial yang tinggi kepada sesama.

Kecerdasan spiritual adalah kecerdasan untuk menghadapi dan memecahkan persoalan makna dan nilai, yaitu kecerdasan untuk menempatkan perilaku dan hidup kita dalam konteks makna yang lebih luas dan kaya, kecerdasan untuk menilai bahwa tindakan atau jalan hidup seseorang lebih bermakna dibandingkan dengan yang lain (Zohar \& Marshall, 2007).

Zohar dan Marshall (2007) mengungkap bahwa kecerdasan spiritual terdiri dari dimensi-dimensi sebagai berikut: Kemampuan bersikap fleksibel, tingkat kesadaran yang tinggi, kemampuan untuk menghadapi dan memanfaatkan penderitaan, kemampuan untuk menghadapi dan melampaui rasa sakit, kualitas hidup yang diilhami oleh visi dan nilai-nilai, keengganan untuk menyebabkan kerugian yang tidak perlu, kemampuan untuk melihat keterkaitan dalam berbagai hal (berpandangan holistik), dan memiliki kecenderungan bertanya.

Tujuan diadakannya penelitian ini adalah untuk menguji hubungan antara kecerdasan spiritual dengan komitmen organisasi Sedangkan hipotesis yang diajukan dalam penelitian ini adalah terdapat hubungan yang positif dan signifikan antara kecerdasan spiritual dengan komitmen organisasi pada mahasiswa pengurus UKK dan UKM di UIN Antasari Banjarmasin. 


\section{Metode}

Metode yang digunakan dalam penelitian ini adalah metode penelitian kantitatif. Dalam penelitian ini yang dijadikan subjek penelitian adalah mahasiswa aktif pengurus Unit Kegiatan Khusus (UKK) dan Unit Kegiatan Mahasiswa (UKM) di Universitas Islam Negeri Antasari Banjarmasin periode 2017/2018 yang populasinya berjumlah 919 orang menurut hasil pengmbilan data yang dilakukan pada 5 UKK dan 14 UKM dan yang dijadikan sampel dalam penelitian berjumlah 10persen (92 orang). Teknik pengambilan sampel yang digunakan adalah random sampling. Teknik ini dikatakan simple atau sederhana karena pengambilan anggota sampel dari populasi dilakukan secara acak tanpa memperhatikan strata yang ada dalam populasi itu (Sugiyono, 2015). Cara demikian dilakukan bila anggota populasi dianggap homogen. Sampel dalam penelitian ini ditentukan oleh peneliti, untuk kekonsistenan proporsi yang diambil pada setiap UKK dan UKM adalah 10persen dari populasi tiap organisasi UKK dan UKM. Penetapan besar-kecilnya sampel tidaklah ada suatu ketetapan yang mutlak, artinya tidak ada suatu ketentuan berapa persen suatu sampel harus diambil (Arikunto, 2015).

Alat ukur yang digunakan untuk mengumpulkan data dalam penelitian ini adalah skala kecerdasan spiritual oleh Zohar dan Marshall kemudian diadaptasi dengan model skala deskriptif dari Likert atau sering disebut skala likert, dan skala komitmen organisasi oleh Allen dan Mayer yg kemudia diadaptasi dengan model skala deskriptif dari likert atau sering disebut skala likert.

Proses analisis data dilakukan dengan menggunakan program SPSS 21.0 for Windows. Setelah keseluruhan data yang dibutuhkan telah terkumpul, maka peneliti melakukan uji asumsi yang meliputi uji normalitas dan uji linieritas. Uji normalitas dilakukan untuk mengetahui normal tidaknya sebaran skor variabel kecerdasan spiritual dan komitmen organisasi (Assidiqi, 2015). Uji normalitas sebaran data penelitian menggunakan Teknik Kolmogorov-Smirnov.

\section{Hasil}

Hasil uji normalitas variabel komitmen organisasi dan kecerdasan spiritual menunjukkan nilai signifikasi Kolmogorov-smirnov sebesar 0,352 ( $p>0,05)$. Hal ini 
menunjukkan bahwa data komitmen organisasi dan kecerdasasn spiritual dalam penelitian ini memiliki data yang berdistribusi normal. Sedangkan hasil uji linieritas menunjukkan nilai linieritas sebesar 0,002 ( $\mathrm{p}<0,05)$. Hal ini menunjukkan bahwa terdapat hubungan linear antara kedua variable (Winarsunu, 2012).

Hasil analisis korelasi menunjukkan bahwa nilai signifikasi sebesar 0,002 $(\mathrm{p}<0,05)$ menunjukkan adanya korelasi atau hubungan yang sangat signifikan antara variabel komitmen organisasi dan kecerdasan spiritual. Untuk lebih jelasnya berikut ini adalah tabel hasil korelasi product moment:

Tabel 7

Correlasion Product Moment

\begin{tabular}{ccccc}
\hline Model & $R$ & $R$ Square & Adjusted $R$ Square & Std. Error of the Estimate \\
\hline 1 &, $313^{\text {a }}$ &, 098 &, 088 & 7,983 \\
\hline
\end{tabular}

Berdasarkan tabel 7 diketahui bahwa besarnya nilai korelasi atau hubungan yaitu sebesar 0,313 yang dalam hal ini berarti termasuk dalam kategori hubungan rendah, dan nilai koefisien determinasi ( $R$ Square) sebesar 0,98 yang berarti bahwa pengaruh kecerdasan spiritual terhadap komitmen organisasi adalah sebesar 9,8 persen.

Selanjutnya, untuk mencari makna atau arah hubungan antara variabel $\mathrm{X}$ dan variabel $\mathrm{Y}$ maka dilakukan uji signifikansi dengan hipotesis yang telah diajukan oleh peneliti. Dasar pengambilan keputusan tersebut jika nilai probabilitas $\alpha$ lebih besar dari pada atau sama dengan nilai probabilitas Sig.(0,05 $\geq$ Sig.), maka Ha diterima artinya signifikan (Sugiyono, 2016).

Berdasarkan hasil perhitungan uji korelasi dengan menggunakan Teknik Pearson Product Moment maka didapatkan hasil uji arah atau hubungan antara variabel adalah 0,05 $\geq$ Sig. $=0,05 \geq$ 0,002. Maka hipotesis yang menyatakan bahwa ada hubungan yang signifikan antara kecerdasan spiritual dengan komitmen organisasi diterima. Sehingga dapat ditarik kesimpulan bahwa terdapat hubungan antara kecerdasan spiritual dengan komitmen organisasi.

Berdasarkan hasil koefisien korelasi tersebut juga dapat diketahui bahwa korelasinya bersifat positif, artinya semakin tinggi kecerdasan spiritual maka semakin tinggi pula komitmen organisasi. Sebaliknya, jika kecerdasan spiritual rendah maka akan rendah pula 
komitmen organisasi para pengurus UKK dan UKM di UIN Antasari Banjarmasin. Berikut ini adalah data tabel yang akan menjabarkan tentang tingkat komitmen organisasi dan kecerdasan spiritual:

Tabel 8

Tingkat Komitmen Organisasi Mahasiswa

\begin{tabular}{cccccc}
\hline & Kategori & $F$ & $\%$ & Valid Percent & Cumulative Percent \\
\hline \multirow{4}{*}{ Valid } & Tinggi & 17 & 18,5 & 18,5 & 18,5 \\
& Sedang & 61 & 66,3 & 66,3 & 84,8 \\
& Rendah & 14 & 15,2 & 15,2 & 100,0 \\
& Total & 92 & 100,0 & 100,0 & \\
\hline
\end{tabular}

Berdasarkan tabel di atas dapat diketahui bahwa tingkat komitmen organisasi mahasiswa pengurus UKK dan UKM di Universitas Islam Negeri Antasari Banjarmasin dengan kategori tinggi sebesar 18,5 persen (17 orang), intensitas sedang sebesar 66,3 persen (61 orang), dan intensitas rendah sebesar 15,2 persen (14 orang). Sedankan untuk data tingkat kecerdasan spiritual adalah sebagai berikut:

Tabel 9

Tingkat Kecerdasan Spiritual Mahasiswa

\begin{tabular}{cccccc}
\hline \multicolumn{2}{c}{ Kategori } & $F$ & $\%$ & Valid Percent & Cumulative Percent \\
\hline \multirow{4}{*}{ Valid } & Tinggi & 15 & 16,3 & 16,3 & 16,3 \\
& Sedang & 59 & 64,1 & 64,1 & 80,4 \\
& Rendah & 18 & 19,6 & 19,6 & 100,0 \\
& Total & 92 & 100,0 & 100,0 & \\
\hline
\end{tabular}

Berdasarkan tabel di atas dapat diketahui bahwa tingkat kecerdasan spiritual mahasiswa pengurus UKK dan UKM di Universitas Islam Negeri Antasari Banjarmasin dengan kategori tinggi sebesar 16,3 persen (15 orang), intensitas sedang sebesar 64,1 persen (59 orang), dan intensitas rendah sebesar 19,6 persen (18 orang).

Kemudian untuk menjawab rumusan masalah yang ketiga tentang apakah ada hubungan antara kecerdasan spiritual dengan komitmen organisasi, dari hasil penelitian ini diperoleh data bahwa besar hubungan antara kecerdasan spiritual dengan komitmen organisasi adalah $\left(r x y^{2}\right.$ x 100) sebesar 9,8persen, ini artinya ada indikator lain sebesar 90,2 persen yang 
memiliki hubungan dengan komitmen organisasi selain kecerdasan spiritual yang dalam hal ini tidak diteliti lebih lanjut oleh peneliti. Hasil analisis tersebut dapat diartikan bahwa semakin tinggi kecerdasan spiritual semakin tinggi pula komitmen organisasinya.

\section{Pembahasan}

Sheldon mendefinisikan komitmen sebagai suatu orientasi terhadap organisasi yang menghubungkan atau melekatkan individu pada organisasi tersebut. Komitmen adalah hal penting dalam suatu organisasi karena komitmen dapat menjadi suatu alasan mengapa individu tetap bertahan dalam organisasi tersebut. Menurut Allen dan Mayer (Luthans, 2010) anggota dengan komitmen afektif yang kuat tetap berada dalam organisasi karena menginginkannya. Anggota dengan komitmen kesinambungan yang kuat tetap dalam organisasi karena membutuhkannya (need to), sedangkan karyawan yang memiliki komitmen yang normatif kuat tetap berada dalam organisasi karena mereka harus melakukan (tought to).

Gambaran komitmen organisasi ditinjau melalui dimensi-dimensi yang dikemukakan oleh Allen dan Mayer (Luthans, 2010). Dimensi yang dimuat dalam skala sesuai dengan teori yang sudah dituangkan oleh peneliti dalam definisi operasional dan landasan teori yaitu dimensi yang berkaitan dengan tingakat komitmen organisasi, diantaranya adalah komitmen afektif, komitmen kesinambungan dan komitmen normatif.

Faktor yang dianggap oleh peneliti memiliki hubungan dengan komitmen organisasi adalah kecerdasan spiritual. Kecerdasan spiritual menurut Zohar dan Marshall (2007) adalah kecerdasan untuk menghadapi dan memecahkan persoalan makna dan nilai, yaitu kecerdasan untuk menempatkan perilaku dan hidup kita dalam konteks makna yang lebih luas dan kaya, kecerdasan untuk menilai bahwa tindakan atau jalan hidup seseorang lebih bermakna dibandingkan dengan yang lain (Ginanjar, 2016).

Gambaran kecerdasan spiritual ditinjau melalui ciri-ciri atau tanda-tanda yang dikemukakan oleh Zohar dan Marshall (2007). Ciri-ciri atau tanda-tanda tersebut dimuat dalam skala sesuai dengan teori yang sudah dituangkan oleh peneliti dalam definisi operasional dan landasan teori dimana ciri-ciri atau tanda-tanda tersebut berkaitan dengan perilaku yang menggambarkan kecerdasan spiritual seseorang seperti; memiliki kemampuan bersikap 
fleksibel, memiliki tingkat kesadaran yang tinggi, memiliki kemampuan untuk menghadapi dan memaafkan penderitaan, memiliki kemampuan untuk menghadapi dan melampaui rasa sakit, memiliki kualitas hidup yang diilhami oleh visi dan nilai-nilai, enggan untuk menyebabkan kerugian yang tidak perlu, memiliki kemampuan untuk melihat keterkaitan dalam berbagai hal (berpandangan holistik), memiliki kecenderungan bertanya dan mandiri.

Dari penelitian ini diketahui dengan jelas bahwa terdapat hubungan yang signifikan antara kecerdasan spiritual dengan komitmen organisasi pada mahasiswa pengurus UKK dan UKM di Universitas Islam Negeri Antasari Banjarmasin. Adapun hal tersebut menyatakan bahwa ada hubungan positif sebesar 0,313. Hal tersebut menyatakan bahwa ada hubungan positif tetapi dalam tingkat hubungan yang rendah antara kecerdasan spiritual dengan komitmen organisasi.

Menjawab rumusan masalah yang pertama tentang tingkat kecerdasan spiritual, dari hasil penelitian ini diperoleh data bahwa komitmen organisasi berada dikategori tinggi 17 orang (18,5 persen), dikategori sedang 61 orang (66,3 persen) dan yang dikategori rendah 14 orang (15,2 persen). Selanjutnya untuk menjawab rumusan masalah yang kedua tentang tingkat kecerdasan spiritual berada dikategori tinggi 15 orang (16,3 persen), dikategori sedang 59 orang (64,1 persen) dan yang dikategori rendah 18 orang (19,6 persen), dari hasil penelitian ini diperoleh data bahwa. Kemudian untuk menjawab rumusan masalah yang ketiga tentang apakah ada hubungan antara kecerdasan spiritual dengan komitmen organisasi, dari hasil penelitian ini diperoleh data bahwa besar hubungan antara kecerdasan spiritual dengan komitmen organisasi adalah (rxy2 x 100) sebesar 9,8 persen, ini artinya ada indikator lain sebesar 90,2 persen yang memiliki hubungan dengan komitmen organisasi selain kecerdasan spiritual yang dalam hal ini tidak diteliti lebih lanjut oleh peneliti. Hasil analisis tersebut dapat diartikan bahwa semakin tinggi kecerdasan spiritual semakin tinggi pula komitmen organisasinya.

Sesuai dengan hasil analisis, maka dapat diambil kesimpulan bahwa terdapat hubungan positif antara kecerdasan spiritual dengan komitmen organisasi pada mahasiswa pengurus UKK dan UKM di UIN Antasari Banjarmasin, tetapi dalam tingkat hubungan yang rendah, hal ini menyatakan bahwa komitmen organisasi seseorang tidak mesti ada hubungannya dengan 
kecerdasan spiritual yang dimiliki oleh individu. Antara kecerdasan spiritual dengan komitmen organisasi memang saling berdekatan, akan tetapi bisa saja seseorang yang memiliki komitmen organisasi yang tinggi dikarenakan faktor-faktor penyebab lainnya.

Rendahnya hubungan antara komitmen organisasi dengan kecerdasan spiritual dikarenakan komitmen organisasi tidak hanya dipengaruhi oleh satu faktor saja, hal demikian sesuai dengan teori yang dikemukakan oleh Daniel Goleman yang menyatakan bahwa perkembanagn manusia sangat dipengaruhi oleh dua faktor, yaitu internal dan eksternal (Sunar, 2010). Hal ini juga dapat dibuktikan dengan salah satu penelitian yang dilakukan oleh Yuanita Candra (2007) dalam sebuah jurnal yang berjudul "Relation Between Perception to Organizational Change with Affective Commitment Worker of Bank Rakyat Indonesia (BRI) Syariah" dalam penelitian tersebut dikemukakan bahwa salah satu hal penting yang membuat seseorang mempunyai komitmen terhadap organisasinya adalah keterikatan emosional. Dalam penelitian tersebut juga dijelaskan bahwa rasa aman dari lingkungan juga menjadi salah satu faktor pendukung komitmen organisasi. Pada kesimpulannya dapat diketahui bahwa selain kecerdasan emosional yang berasal dari dalam diri individu ada faktor lain yang menunjang komitmen organisasi yaitu faktor eksternal yang berasal lingkungan organisasinya.

Donna M. Randall (Tobing, 2009) dari Washington State University mencoba membahas mengenai konsekuensi positif dan negatif dari berbagai macam tingkatan komitmen, baik bagi anggota maupun bagi organisasi. Seperti yang telah dipaparkan pada bab sebelumnya bahwa tingkat komitmen yang berada dalam kategori moderat atau sedang juga memilik beberapa konsekuensi, baik positif maupun negatif sebagai berikut:

1. Konsekuensi positif bagi individu. Tingkat komitemen yang moderat atau sedang bukan berarti komitmen seseorang tidak terikat pada organisasi, tetapi individu menghindari menerima begitu saja. Jadi, tingkat komitmen yang moderat merefleksikan kemampuan untuk menerima nilai-nilai organisasi, tetapi tidak semua. Individu mempertahankan integritas dan nilai-nilai pribadi sekaligus memenuhi keperluan organisasi.

2. Konsekuensi positif bagi individu. Konsekuensi positif bagi organisasi dan juga bagi individu adalah dapat berupa, masa kerja yang lama, kurangnya keinginan untuk keluar, turn over yang rendah, dan semakin besarnya kepuasan kerja. 
3. Konsekuensi negatif bagi individu. Komitmen yang moderat terhadap organisasi tidak selalu optimal bagi individu. Individu yang tidak memberikan prioritas pada organisasi bisa menghadapi penempatan posisi jabatan yang tidak pasti dalam organisasi.

4. Konsekuensi negatif bagi organisasi. Individu yang tidak komit sepenuhnya terhadap organisasi mungkin membatasi peran ekstra bagi organisasi. Smit, Organ, dan Near mengatakan bahwa citizenship behaviuor seperti: kerja sama, suka membantu, suka memberi saran, suka menolong adalah hal penting karena dapat menjadikan organisasi dengan fleksibilitas yang diperlukan untuk mengatasi kemungkinan-kemungkinan yang tak terduga.

Komitmen anggota pada organisasi tidak terjadi begitu saja, tetapi melalui proses yang panjang dan bertahap. Komitmen anggota pada organisasi juga ditentukan oleh sejumlah faktor. Menurut Strees ada tiga faktor yang mempengaruhi komitmen anggota pada organisasinya, yaitu: Ciri pribadi kinerja, termasuk masa jabatan dalam organisasi dan variasi kebutuhan dan keinginan yang berbeda dari tiap anggota. Kemudian ciri pekerjaan, seperti identitas tugas dan kesempatan berinteraksi dengan rekan kerja dalam organisasi tersebut dan pengalaman kerja, seperti keterandalan organisasi dimasa lampau dan cara anggota mengutarakan dan membicarakan perasaannya mengenai organisasi (Mulyaningsih \& Padmantyo, 2016).

Kategori komitmen organisasi mahasiswa pengurus UKK dan UKM di UIN Antasari Banjarmasin termasuk kategori sedang, dalam artian bisa dikatakan sudah dalam kondisi yang baik, hanya saja perlu lebih ditingkatkan lagi. Hal ini di karenakan di dalam organisasi pada umumnya mahasiswa banyak yang masih belajar bagaimana menjalani tugas-tugasnya diorganisasi, dan juga organisasi kemahasiswaan yang ada di kampus bersifat sukarela, artinya tidak ada yang dibayar untuk menjadi bagian dari organisasi. Kurikulum perkuliahan yang semakin padat juga menjadi salah satu alasan mengapa komitmen organisasi yang dimiliki mahasiswa termasuk dalam kategori sedang. Selain itu rasa memiliki pada organisasi yang kurang juga bisa menyebabkan komitmen organisasi pada mahasiswa berada dalam kategori sedang. 
Faktor lain yang menyebabkan komitmen organisasi berada dalam kategori sedang adalah pada organisasi UKK dan UKM di UIN Antasari Banjarmasin, para pengurus organisasi tidak hanya difokuskan mengerjakan tugas organisasi saja, akan tetapi ada tugas utama lain yang pasti didahulukan oleh mereka yaitu kuliah. Karena tujuan utama mereka di kampus UIN Antasari Banjarmasin adalah untuk menuntut ilmu. Seperti yang telah dijelaskan sebelumnya juga, bahwa kurangnya keterikatan emosional para pengurus menjadi salah satu faktor yang menyebabkan kurangnya komitmen organisasi pengurus. Sedangkan dalan teori komitmen organisasi dijelaskan bahwa seseorang yang memiliki keterikatan emosional anggota pada organisasi akan terus menerus bekerja dalam organisasi karena mereka memang ingin melakukan hal tersebut.

Pada kategori kecerdasan spiritual mahasiswa pengurus UKK dan UKM di UIN Antasari Banjarmasin termasuk kategori sedang, hal ini dikarenakan dalam menjalani kegiatan sehari-hari tidak hanya kecerdasan spiritual saja yang berperan penting. Pada umumnya mahasiswa yang menjadi pengurus organisasi memiliki karakter yang berbeda-beda dan dari latar belakang yang berbeda. Selain kecerdasan spiritual ada kecerdasan lain yang juga memiliki peran penting dalam kehidupan sehari-hari yaitu kecerdasan intelektual, dan kecerdasan emosional. Seperti yang diungkapkan oleh Daniel Golemen bahwa kontribusi IQ bagi keberhasilan seseorang hanya sekitar 20 persen dan sisanya yang 80 persen ditentukan oleh serumpun faktor-faktor yang disebut kecerdasan emosional. Oleh karena itu bisa saja seseorang yang memiliki tingkat kecerdasan spiritual dalam kategori sedang tetapi bisa saja dalam kecerdasan lain seseorang itu berada dalam kategori tinggi, dan juga seperti yang telah dipaparkan sebelumnya bahwa banyak faktor lain selain kecerdasan spiritual yang menyebabkan seseorang memiliki komitmen yang tinggi pada organisasi. Adapun faktor-faktor yang mempengaruhi kecerdasan spiritual adalah inner value (nilai-nilai spiritual dari dalam) yang berasal dari dalam diri, suara hati, tanggung jawab, adil dan kesadaran sosial. Kemudian drive yaitu dorongan dan usaha untuk mencapai kebenaran dan kebahagiaan.

Toto Tasmara (2001) mendefinisikan kecerdasan spiritual adalah kemampuan seseorang untuk mendengarkan hati nuraninya, baik dan buruk dan rasa moral dalam cara menempatkan diri dalam pergaulan. Teori yang dikemukakan oleh Toto Tasmara (20001). menjelaskan bahwa 
kecerdasan spiritual salah satunya meliputi kemampuan seseorang dalam menempatkan diri dalam pergaulan. Hal ini selaras dengan salah satu faktor pendukung komitmen organisasi yaitu ciri pekerjaan yang menekankan bahwa komitmen organisasi meliputi identitas tugas dan kesempatan berinteraksi dengan rekan kerja dalam organisasi tersebut. Kecerdasan spiritual dalam Islam menekankan segala sesuatunya berasal dari hati, sesuai dengan hadits nabi Muhammad saw yang memaparkan bahwa apabila segumpal darah dalam diri manusia itu baik maka baik pulalah tubuh tersebut. Hati yang dimaksud haruslah memiliki hubungan yang kuat dengan Allah, menyerahkan seluruh hidupnya dengan penuh ridha, pasrah dan mengabdi dengan ikhlas setelah itu barulah menghasilkan kekuatan luar biasa yang sangat besar terhadap diri pribadi seseorang. Maka akan bangkitlah kekuatan dan kecerdasan juga membangun tanggung rasa tanggung jawab dengan terus melakukan amal shaleh.

Salah satu cara untuk mendapatkan kekuatan yang luar biasa terhadap diri seseorang adalah dengan meningkatkan kualitas hubungannya dengan Allah Swt, dengan begitu kecerdasan spiritualnya akan meningkat dan juga akan membangun rasa tanggung jawab pada diri pribadi. Maka dengan kecerdasan spiritual yang meningkat akan membuat kita lebih bertanggung jawab lagi dengan apa yang kita lakukan dalam hidup, hal ini akan membuat komitmen organisasi seseorang meningkat atau berkembang. Jadi, salah satu cara untuk meningkatkan komitmen organisasi adalah dengan meningkatkan kecerdasan spiritual dalam diri pribadi kita. Salah satu caranya adalah dengan meningkatkan kualitas hidup dan mendekatkan diri kepada Allah Swt.

Sebagai penelitian yang dilakukan dalam lingkup pendidikan maka implikasi penelitian ini diharapkan mampu memperluas wawasan mahasiswa yang berorganisasi tentang pentingnya kecerdasan spiritual dan komitmen organisasi. Penelitian ini juga diharapkan mampu dijadikan referensi untuk mahasiswa yang akan melakukan penelitian selanjutnya.

\section{Kesimpulan}

Berdasarkan hasil uji korelasi dalam penelitian ini, dapat disimpulkan bahwa terdapat hubungan yang positif antara kecerdasan spiritual dengan komitmen organisasi pada mahasiswa pengurus Unit Kegiatan Khusus (UKK) dan Unit Kegiatan Mahasiswa (UKM) di 
Universitas Islam Negeri Antasari Banjarmasin periode 2017/2018. Dengan kata lain, semakin tinggi kecerdasan spiritual, maka semakin tinggi komitmen organisasi seseorang dan begitupun sebaliknya. Kecerdasan spiritual akan menolong seseorang untuk memutuskan tindakan yang tepat dan memikirkan dampak yang akan ditimbulkan oleh tindakannya. Oleh karena itu, bagi para pengurus organisasi yang memiliki kecerdasan spiritual yang tinggi maka akan memiliki komitmen organisasi yang tinggi pula.

Saran

Adapun saran untuk penelitian selanjutnya, harapannya bisa lebih banyak mencantumkan teori-teori terbaru terkait komitmen organisasi dan kecerdasan spiritual. Selain itu tidak menghabiskan waktu yang banyak dalam hal penggalian data sehingga dapat memaksimalkan dalam pengambilan data selanjutnya. Selain itu, Bagi peneliti selanjutnya diharapkan dapat meneliti variabel lain dari faktor-faktor yang dapat mempengaruhi komitmen organisasi, baik secara internal maupun eksternal, serta hubungan kecerdasan spiritual terhadap variabel lain. Pada penelitian selanjutnya juga diharapkan dapat meneliti lebih lanjut lagi tentang aspek mana saja yang berpengaruh lebih besar untuk meningkatkan variabel komitmen organisasi.

\section{Referensi}

Arikunto, S. (2015). Prosedur Penelitian Suatu Pendekatan Praktek. Yogyakarta: Pustaka Pelajar. Assidiqi, H. (2015). Paduan IBM SPSS 22. Banjarmasin: Labkom PMTK UIN Antasari.

Candra, Y. (2007). Relation Between Perception to Organizational Change with Affective Commitment Worker of Bank Rakyat Indonesia (BRI) Syariah. Jurnal Biennial International Conference on I/O Psychology.

Fibrianti, I. D. (2009). Hubungan antara Dukungan Sosial Orangtua dengan Prokratinasi Akademik dalam Menyelesaikan Skripsi pada Mahasiswa Fakultas Psikologi Universitas Diponegoro Semarang.

Ginanjar, A. (2016). Rahasia Sukses Menggunakan Kecerdasan Emosi dan Spiritual ESQ: Emotional Spiritual Quotient Berdasarkan 6 Rukun Iman dan 5 Rukun Islam. Jakarta: Arga.

Luthans, F. (2016). Perilaku Organisasi, terj. Vivin Andhika Yuwanto, Shekar Purwanti, Th. Arie P dan Winong Rosari. Yogyakarta: ANDI.

Luthans, L. A. (2010). Psikologi Umum. Jakarta: Salemba Humanika.

Mulyaningsih, M., \& Sri Padmantyo, M. (2016). Analisis Faktor-Faktor Yang Mempengaruhi Komitmen Kerja Karyawan Studi Pada Karyawan Batik Brotoseno Sragen. 
Sugiyono. (2015). Statistika untuk penelitian. Bandung: Alfabeta.

Sugiyono. (2016). Metode penelitian kuantitatif, kulaitatif dan RED. Bandung: Alfabeta.

Sunar, P. D. (2010). Edisi Lengkap tes IQ, EQ dan SQ. Yogyakarta: Flash Books.

Tasmara, T. (2001). Kecerdasan Ruhaiah (Transcedental Intellgence: Membentuk Kepribadian Yang Bertanggung Jawab, Profesional dan Berakhlak). Jakarta: Gema Insani.

Tobing, D. S. K. (2009). Pengaruh komitmen organisasional dan kepuasan kerja terhadap kinerja karyawan PT. Perkebunan Nusantara III di Sumatera Utara. Jurnal manajemen dan kewirausahaan, 11(1), 31-37.

Winarsunu, T. (2012). Statistik dalam Penelitian Psikologi dan Pendidikan. Malang: UMM Press.

Zohar, D., \& Marshall, I. (2007). SQ: Kecerdasan Spiritual. Bandung: Mizan. 